Atmos. Chem. Phys., 17, 10619-10631, 2017

https://doi.org/10.5194/acp-17-10619-2017

(c) Author(s) 2017. This work is distributed under

the Creative Commons Attribution 3.0 License.

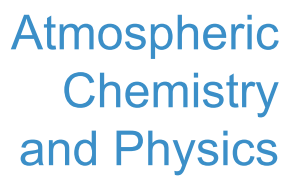

(c) (P)

\title{
Decoupling peroxyacetyl nitrate from ozone in Chinese outflows observed at Gosan Climate Observatory
}

\author{
Jihyun Han ${ }^{1, \text { a }}$, Meehye Lee ${ }^{1}$, Xiaona Shang ${ }^{1}$, Gangwoong Lee ${ }^{2}$, and Louisa K. Emmons ${ }^{3}$ \\ ${ }^{1}$ Department of Earth and Environmental Sciences, Korea University, Seoul, Republic of Korea \\ ${ }^{2}$ Department of Environmental Science, Hankuk University of Foreign Studies, Yongin, Republic of Korea \\ ${ }^{3}$ Atmospheric Chemistry Observations and Modeling Laboratory, National Center for Atmospheric Research (NCAR), \\ Boulder, CO, USA \\ ${ }^{a}$ now at: Korea Environment Institute, Sejong, Republic of Korea
}

Correspondence to: Meehye Lee (meehye@ korea.ac.kr)

Received: 8 December 2016 - Discussion started: 25 January 2017

Revised: 7 July 2017 - Accepted: 21 July 2017 - Published: 8 September 2017

\begin{abstract}
We measured peroxyacetyl nitrate (PAN) and other reactive species such as $\mathrm{O}_{3}, \mathrm{NO}_{2}, \mathrm{CO}$, and $\mathrm{SO}_{2}$ with aerosols including mass, organic carbon (OC), and elemental carbon (EC) in $\mathrm{PM}_{2.5}$ and $\mathrm{K}^{+}$in $\mathrm{PM}_{1.0}$ at Gosan Climate $\mathrm{Ob}$ servatory in Korea $\left(33.17^{\circ} \mathrm{N}, 126.10^{\circ} \mathrm{E}\right)$ during 19 October6 November 2010. PAN was determined through fast gas chromatography with luminol chemiluminescence detection at $425 \mathrm{~nm}$ every $2 \mathrm{~min}$. The PAN mixing ratios ranged from 0.1 (detection limit) to $2.4 \mathrm{ppbv}$ with a mean of $0.6 \mathrm{ppbv}$. For all measurements, PAN was unusually better correlated with $\mathrm{PM}_{2.5}$ (Pearson correlation coefficient, $\gamma=0.79$ ) than with $\mathrm{O}_{3}(\gamma=0.67)$. In particular, the $\mathrm{O}_{3}$ level was highly elevated with $\mathrm{SO}_{2}$ at midnight, along with a typical midday peak when air was transported rapidly from the Beijing areas. The PAN enhancement was most noticeable during the occurrence of haze under stagnant conditions. In Chinese outflows slowly transported over the Yellow Sea, PAN gradually increased up to $2.4 \mathrm{ppbv}$ at night, in excellent correlation with a concentration increase in $\mathrm{PM}_{2.5} \mathrm{OC}$ and $\mathrm{EC}, \mathrm{PM}_{2.5}$ mass, and $\mathrm{PM}_{1.0} \mathrm{~K}^{+}$. The high $\mathrm{K}^{+}$concentration and $\mathrm{OC} / \mathrm{EC}$ ratio indicated that the air mass was impacted by biomass combustion. This study highlights PAN decoupling with $\mathrm{O}_{3}$ in Chinese outflows and suggests PAN as a useful indicator for diagnosing continental outflows and assessing their perturbation of regional air quality in northeast Asia.
\end{abstract}

\section{Introduction}

At the surface, ozone is primarily photochemically produced, and the contribution from the stratosphere is generally small. Ozone is formed through reactions of various precursors such as $\mathrm{CO}, \mathrm{CH}_{4}$, volatile organic compounds (VOCs), and $\mathrm{NO}_{x}$ (e.g., Brasseur et al., 1999; Jacob, 2000; Nielsen et al., 1981). Likewise, peroxyacetyl nitrate (PAN) is a secondary product of urban air pollution and a significant oxidant in the atmosphere (e.g., Hansel and Wisthaler, 2000; LaFranchi et al., 2009; Lee et al., 2012; Liu et al., 2010; Roberts et al., 2007). PAN is solely produced by the photochemical reaction between the peroxyacetyl radical and nitrogen dioxide, and the peroxyacetyl radical is derived from the $\mathrm{OH}$ oxidation or photolysis of VOCs such as acetaldehyde, methylglyoxal, and acetone (e.g., Fischer et al., 2014; LaFranchi et al., 2009; Lee et al., 2012). For this reason, PAN is a very useful indicator of photochemical air pollution. As thermal decomposition is a major PAN sink in the troposphere (Beine et al., 1997; Jacob, 2000; Kenley and Hendry, 1982; Talukdar et al., 1995), the lifetime of PAN depends on temperature. For example, the PAN lifetime is $\sim 5$ years at $-26^{\circ} \mathrm{C}$ and $1 \mathrm{~h}$ at $20^{\circ} \mathrm{C}$ (Fischer et al., 2010; Zhang et al., 2011). At high altitudes above $\sim 7 \mathrm{~km}$, photolysis becomes the most important loss process for PAN (Talukdar et al., 1995). Because of low solubility, PAN is not prone to atmospheric removal, thereby being more efficiently transported to the free troposphere (e.g., Zhu et al., 2017). Thus, PAN can be an indicator of $\mathrm{NO}_{y}$ concentration in the free troposphere and a guide for 
the long-range transport of $\mathrm{NO}_{x}$ in remote regions (Jacob, 1999).

In the past decades, PAN has been measured not only in urban areas (Aneja et al., 1999; Gaffney et al., 1999; Grosjean et al., 2002; Lee et al., 2008; Tanimoto et al., 1999; Zhang et al., 2014) but also in background regions (Fischer et al., 2011; Kanaya et al., 2007; Lee et al., 2012; Tanimoto et al., 2002), onboard aircraft (Tereszchuk et al., 2013), and ships (Roberts et al., 2007). PAN concentrations were in the range of a few ppbv in urban areas close to VOCs and $\mathrm{NO}_{x}$ sources (Lee et al., 2008; Zhang et al., 2011). In the most remote regions, PAN concentrations were generally in the range of a few pptv (Gallagher et al., 1990; Mills et al., 2007; Muller and Rudolph, 1992; Staudt et al., 2003).

Although $\mathrm{NO}_{x}$ concentration has recently declined in China (Gu et al., 2013; F. Liu et al., 2016; Krotkov et al., 2016), $\mathrm{NO}_{x}$ and VOCs have gradually increased in East Asia, particularly China during the last couple of decades (Akimoto, 2003; Liu et al., 2010; Ohara et al., 2007; Zhao et al., 2013). This led to an increase in the concentrations of photochemical byproducts such as PAN and $\mathrm{O}_{3}$ not only in East Asia (Liu et al., 2010; Wang et al., 2010; Zhang et al., $2009,2011,2014$ ) but also in North America (Fischer et al., 2010, 2011; Jaffe et al., 2007; Zhang et al., 2008). These results were also demonstrated by the GEOS-Chem model (Zhang et al., 2008). In addition to urban plumes, PAN was reported to be enhanced by biomass combustion (Alvarado et al., 2010; Coheur et al., 2007; Zhu et al., 2015, 2017), such as open burning and the use of biofuel, which often takes place in China after crop harvesting (Cao et al., 2006; Duan et al., 2004). Recent satellite studies have also observed the increased PAN in plumes associated with anthropogenic emissions in eastern China and boreal fires in Siberia (Zhu et al., $2015,2017)$. In this context, PAN is a useful tracer for estimating the impact of Chinese outflows on regional air quality in the northern Pacific region.

Gosan Climate Observatory (GCO) is an ideal place to monitor Asian outflows and their transformation and to estimate their impact on air quality over the northern Pacific region (Lee et al., 2007; Lim et al., 2012). In the present study, PAN was first measured continuously at GCO to characterize its variation and source in relation to $\mathrm{O}_{3}$ and to understand the influence of Chinese outflows on the regional air quality.

\section{Experiments}

PAN measurements were conducted at GCO $\left(33.17^{\circ} \mathrm{N}\right.$, $\left.126.10^{\circ} \mathrm{E}\right)$ on Jeju Island from 19 October to 6 November 2010. GCO is located on a cliff at the western edge of Jeju Island. PAN was determined through fast gas chromatography (GC) with luminol chemiluminescence detection, which is described in detail elsewhere (Gaffney et al., 1998; Lee et al., 2008; Marley et al., 2004). Here, we briefly describe the measurement method.
Ambient air was pumped through a $1.6 \mathrm{~m}$ PFA tubing ( $1 / 4$ in. outer diameter) from the roof of the two-story container into a six-port injection valve (Cheminert $\mathrm{C} 22$, Valco Instruments (Houston, TX, USA)) at $100 \mathrm{~mL} \mathrm{~min}^{-1}$ controlled by a mass flow controller (Lee et al., 2012, 2008). The residence time of the inlet was less than $2 \mathrm{~s}$. PAN and $\mathrm{NO}_{2}$ (and peroxypropyl nitrate (PPN) if present) were separated along a $10 \mathrm{~m}$ capillary GC column (DB-1, J\&W Scientific, Folsom, CA, USA), whose end was connected to a luminol cell where the column effluent reacted with luminol, giving off luminescent light (Lee et al., 2008, 2012). The concentrations of PAN and other species were determined from the chemiluminescence signals detected by a gated photon counter (HC135-01, Hamamatsu, Bridgewater, NJ, USA) at $425 \mathrm{~nm}$, which was set to $800 \mathrm{~V}$ and operated at room temperature (Gaffney et al., 1998; Lee et al., 2012, 2008).

PAN was calibrated against standards synthesized by the nitration of peracetic acid in $n$-tridecane (Gaffney et al., 1984; Gregory, 1990; Lee et al., 2008). A few microliter aliquots of standard solution were injected through an injection valve and then mixed with zero air $(99.999 \%)$ in a $5 \mathrm{~L}$ Tedlar bag. After being left for a few minutes for equilibrium, it was injected into the GC-luminol instrument and the $\mathrm{NO}_{x}$ chemiluminescence instrument with a molybdenum converter (42C, Thermo Electron Corporation, Franklin, MA, USA). The calibration was completed within $5 \mathrm{~min}$ to prevent thermal decomposition of the PAN (Kourtidis et al., 1993; Lee et al., 2008). These calibration procedures were carried out on the assumption that the PAN was completely converted to NO in the molybdenum converter. The detection limit of PAN defined by $3 \sigma$ of the lowest standard was no greater than 100 pptv (Lee et al., 2008). The overall measurement uncertainty and precision were estimated to be 16 and $5 \%$, respectively (Lee et al., 2012). The $\mathrm{NO}_{x}$ instrument was calibrated with NO standard gas.

Gaseous species including $\mathrm{O}_{3}, \mathrm{NO}, \mathrm{NO}_{2}, \mathrm{CO}$, and $\mathrm{SO}_{2}$ were measured by UV absorption, chemiluminescence with a molybdenum converter, non-dispersive infrared, and the pulse UV fluorescence method (NIER, 2016a). The measurements were made in compliance with guidelines for the installation and operation of an air pollution monitoring network (NIER, 2016b). Calibration was conducted before and after the experiment, following the regular checkup procedure. The detection limits of $\mathrm{O}_{3}, \mathrm{NO}_{x}, \mathrm{CO}$, and $\mathrm{SO}_{2}$ are 2, 0.1, 50, $0.1 \mathrm{ppb}$, respectively (NIER, 2016b). It should be noted that the $\mathrm{NO}_{2}$ concentration reported in the present study is actually the sum of $\mathrm{NO}_{2}$ and $\mathrm{NO}_{z}$ species due to a well-known positive artifact of the molybdenum convertor. PAN is one of the major $\mathrm{NO}_{z}$ species, and the ratio of PAN to $\mathrm{NO}_{2}$ was $12 \pm 7 \%$ for all measurements.

Aerosol species, including $\mathrm{PM}_{2.5}$ mass and $\mathrm{PM}_{2.5}$ organic carbon (OC) and elemental carbon (EC) were measured and recorded along with meteorological parameters (relative humidity, temperature, and wind direction and speed). Watersoluble ions of $\mathrm{PM}_{1.0}$ were collected by a particle-into-liquid 

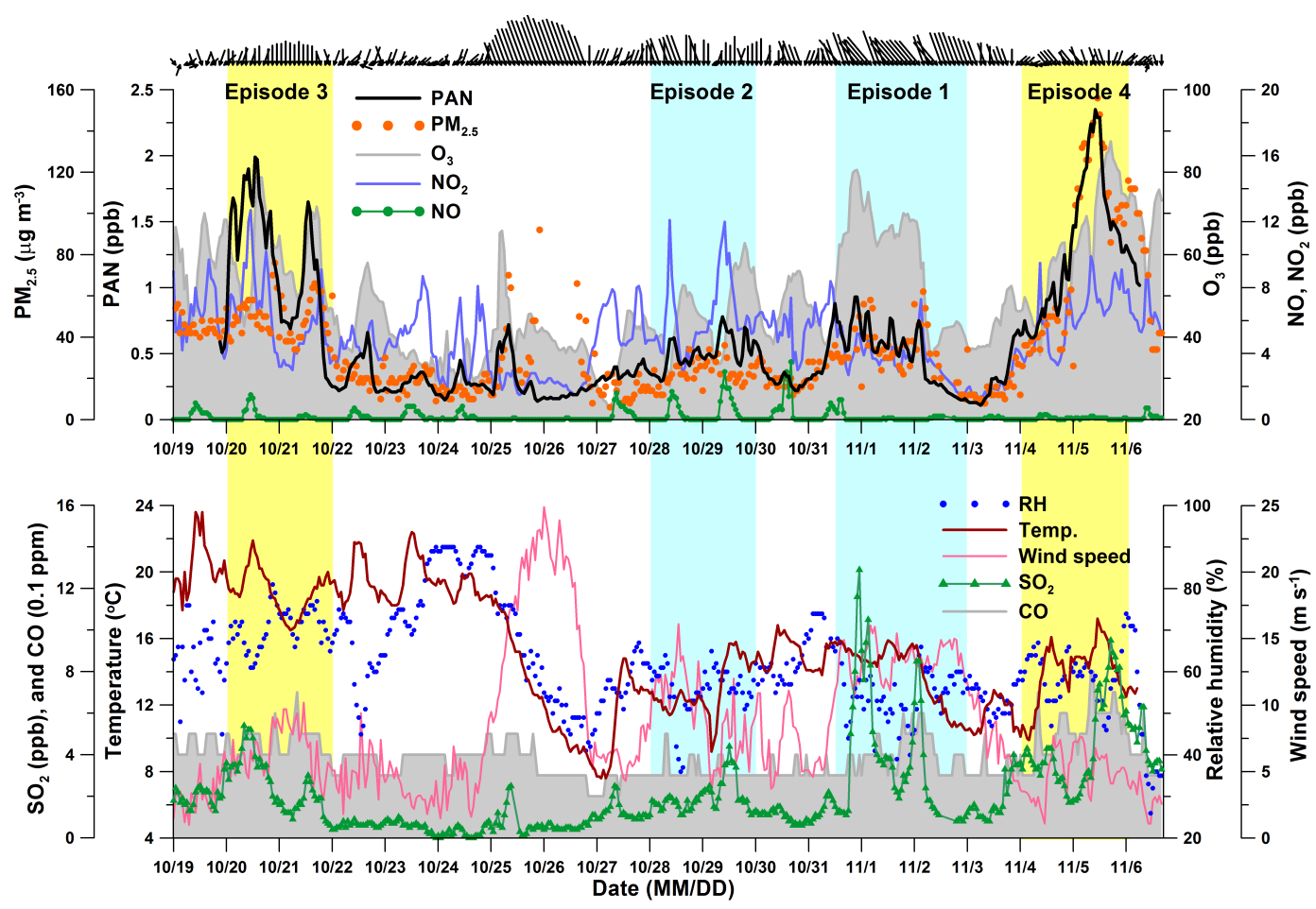

Figure 1. Temporal variations (against local time) of measured species ( $\mathrm{PAN}, \mathrm{PM}_{2.5}, \mathrm{O}_{3}, \mathrm{NO}_{2}, \mathrm{NO}, \mathrm{SO} 2$, and, $\mathrm{CO}$ ) and meteorological parameters (relative humidity, temperature, and wind speed) in fall 2010. Episodes 1-4, described in the main text, are shaded in blue and yellow.

sampler (PILS) and analyzed by ion chromatography. The detailed results of the aerosol measurements can be found in Shang et al. (2017).

For the air parcel at $850 \mathrm{~m}$ a.s.l., the 3-day backward trajectories were calculated every hour using the NOAA Air Resources Laboratory (ARL) Hybrid Single-Particle Lagrangian Integrated Trajectory (HYSPLIT) model (version 4) (Draxler and Rolph, 2012; Rolph, 2012, http://www.arl.noaa. gov/ready/hysplit4.html). In addition, $\mathrm{O}_{3}$ and PAN concentrations were calculated using a global chemistry model, the Community Atmosphere Model with Chemistry (CAMchem), a component of the Community Earth System Model (CESM) (Lamarque et al., 2012; Tilmes et al., 2015). The CAM-chem results shown here follow the configuration used for the HTAP2 (Hemispheric Transport of Air Pollution, Phase 2) intercomparison (e.g., Stjern et al., 2016). CAMchem is nudged to observed meteorology (GEOS-5) to reproduce the actual period of the observations (October 2010). The emissions used in the model are the HTAP2 inventory (Janssens-Maenhout et al., 2015), which include the MIX Asian emissions inventory. Biomass burning emissions are from the Global Fire Emissions Database (GFED3) (Randerson et al., 2013).

\section{Results}

In the present experiments, PAN concentrations range from 0.1 to $2.4 \mathrm{ppbv}$, with an average of $0.6 \mathrm{ppbv}$. This mean value is lower than those observed in other Asian megacities: Beijing (1.41 ppb in the summer), the Pearl River Delta region (1.32 ppb in the summer), and Seoul ( $0.8 \mathrm{ppb}$ in the early summer); it is similar to those of suburban areas in China, e.g., Lanzhou ( $0.76 \mathrm{ppb}$ in the summer), and higher than those of urban and rural sites in Japan (e.g., Tokyo (up to $0.6 \mathrm{ppb}$ in the fall), Rishiri Island ( $\sim 0.5 \mathrm{ppb}$ in spring)), the western coast of the US (e.g., Sacramento $(0.45 \mathrm{ppb}$ in the summer), Mt. Bachelor $(0.144 \mathrm{ppb}$ in the spring and early summer)), off the western coast of the US ( $0.65 \mathrm{ppb}$ in the spring), and over the remote North Pacific (total PAN $<0.3$ ppb in spring) (Bertram et al., 2013; Fischer et al., 2011; LaFranchi et al., 2009; Lee et al., 2008; Roberts et al., 2004; Tanimoto et al., 1999, 2002; Wang et al., 2010; Zhang et al., 2009, 2011). Because the PAN lifetime is greatly dependent on temperature, its concentration decreases with increasing distance from the source regions. The PAN concentrations calculated in this study thus lie in between the levels for the East Asian megacities and the northern Pacific. The distributions of all measured species, including PAN and $\mathrm{O}_{3}$, are presented in Fig. 1. In particular, there are several periods characterized by high concentrations of $\mathrm{PAN}, \mathrm{O}_{3}$, and 

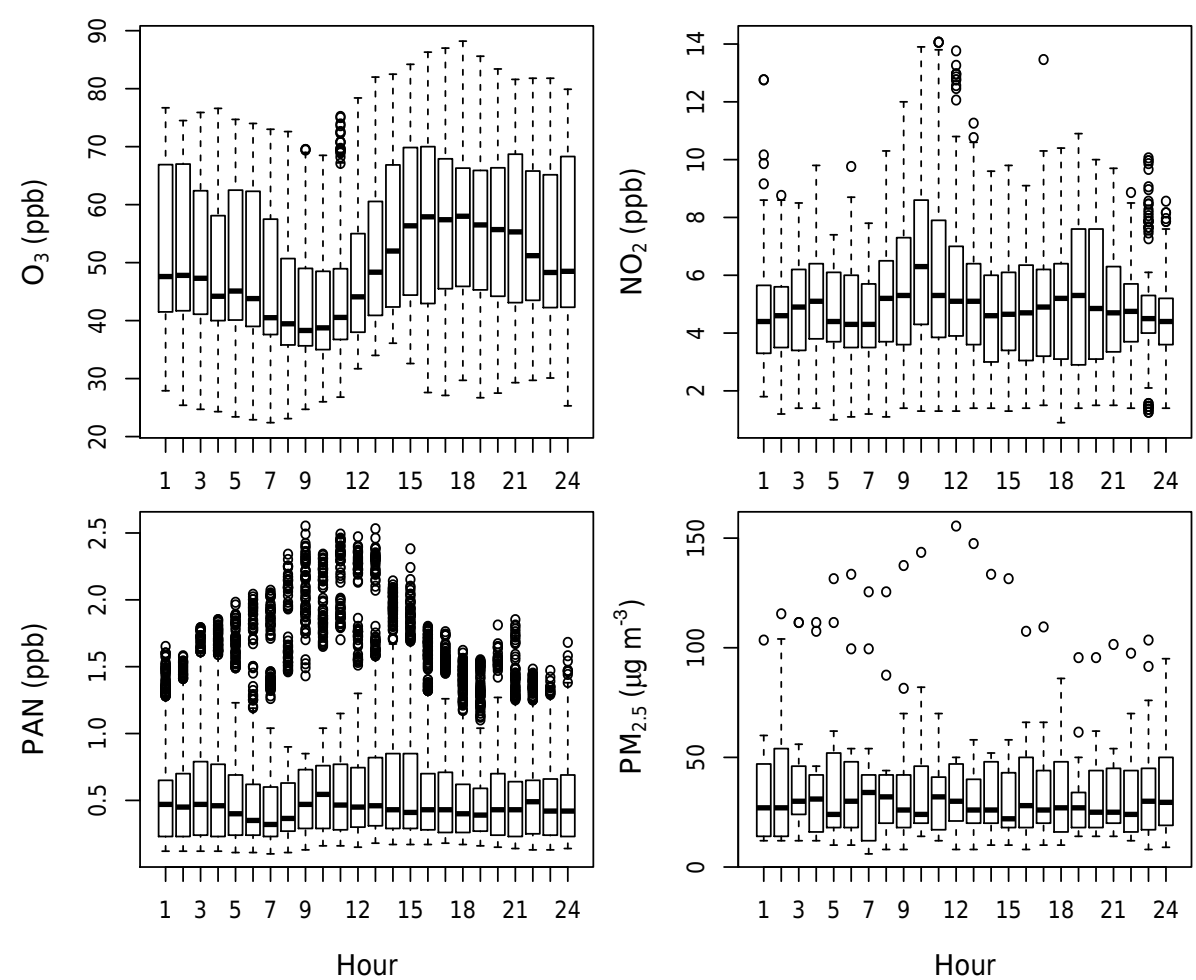

Figure 2. Diurnal variations in the concentrations of $\mathrm{O}_{3}, \mathrm{NO}_{2}, \mathrm{PAN}$, and $\mathrm{PM}_{2.5}$, measured at GCO in the fall of 2010 (5 min data of $\mathrm{O}_{3}$, $\mathrm{NO}_{2} ; 2$ min data of PAN; 1 h data of $\mathrm{PM}_{2.5}$ ).

$\mathrm{PM}_{2.5}$. In terms of PAN, four periods are particularly interesting (Fig. 1). High $\mathrm{O}_{3}$ concentrations were observed during 31 October-2 November (episode 1) but did not coincide with high PAN concentrations. During 28-29 October (episode 2), $\mathrm{NO}_{2}$ was noticeably increased. In comparison, PAN and $\mathrm{O}_{3}$ concentrations were both high during 20-21 October (episode 3) and 4-5 November (episode 4). Episodes 3 and 4 are characterized by haze, while episodes 1 and 2 are characterized by urban influence in the Korean and Beijing outflows, respectively. Haze is reported by the Korea Meteorological Administration (KMA) as a meteorological phenomenon when visibility is $1 \sim 10 \mathrm{~km}$ and relative humidity is less than $75 \%$.

In the present study, PAN correlates reasonably well with $\mathrm{O}_{3}(\gamma=0.67)$ and even better with $\mathrm{PM}_{2.5}(\gamma=0.79)$. In general, $\mathrm{O}_{3}$ and PAN exhibit typical diurnal variation with a maximum recorded in the afternoon, which results in a good correlation between the two (Brasseur et al., 1999; Gaffney et al., 1999; Ridley et al., 1990; Schrimpf et al., 1995; Wang et al., 2010). In this study, however, the $\mathrm{O}_{3}$ peak was often found in the early morning and late afternoon for several days (Fig. 1). Observing the diurnal variations in the entire PAN concentration measurement set (Fig. 2), the maximum was clearly recorded in the morning with the highest outliers, which is rather similar to that of $\mathrm{PM}_{2.5}$. The diurnal pattern of $\mathrm{NO}_{2}$ shows little variation, even though its concentrations were increased in the morning along with PAN. This first measurement of PAN at GCO reveals that PAN is not always coupled with $\mathrm{O}_{3}$, which was not typically observed at remote sites in previous studies (e.g., Fischer et al., 2010; Lee et al., 2012).

\section{Discussion}

\subsection{Decoupling of PAN from $\mathrm{O}_{3}$}

To examine the detailed mechanism of the decoupling of PAN from $\mathrm{O}_{3}$, the daily maximum concentrations of PAN and $\mathrm{O}_{3}$ were further explored. The recorded daily PAN maxima were generally in good correlation with $\mathrm{O}_{3}$, although the relationship did not seem to hold at high concentrations of PAN and $\mathrm{O}_{3}$ (Fig. 3). The daily maxima were then categorized into four groups according to the time when each $\mathrm{O}_{3}$ and PAN maximum was recorded: " $\mathrm{O}_{3}$ day-PAN day", " $\mathrm{O}_{3}$ day-PAN night", " $\mathrm{O}_{3}$ night-PAN day", and " $\mathrm{O}_{3}$ nightPAN night". The day interval started from 08:00 and ended at 18:00 (local time), based on the times of sunrise and sunset during the experiment period. While the high PAN concentrations were associated with the "O $\mathrm{O}_{3}$ day-PAN day" group (cross symbols in Fig. 3), the enhanced $\mathrm{O}_{3}$ concentration was recorded in the " $\mathrm{O}_{3}$ night-PAN night" group (star symbols in Fig. 3). The " $\mathrm{O}_{3}$ night-PAN night" group unexpectedly held more data points than the "O $\mathrm{O}_{3}$ day-PAN day" group, 
Table 1. Chemical and meteorological characteristics of the four episodes.

\begin{tabular}{|c|c|c|c|c|}
\hline & Episode 1 & Episode 2 & Episode 3 & Episode 4 \\
\hline Period & 31 October-2 November & 28-29 October & 20-21 October & 4-5 November \\
\hline Type & Transport dominant & Transport dominant & Chemical transformation & Chemical transformation \\
\hline Event & $\mathrm{O}_{3}$ export & $\mathrm{O}_{3}$ export & Haze & Haze \\
\hline $\mathrm{O}_{3}(\mathrm{ppbv})$ & $60.2(80.6)$ & $45.6(62.8)$ & $59.7(78.9)$ & $61.8(87.5)$ \\
\hline PAN (ppbv) & $0.5(0.9)$ & $0.5(0.8)$ & $1.2(2.0)$ & $1.3(2.4)$ \\
\hline $\mathrm{PM}_{2.5}\left(\mu \mathrm{g} \mathrm{m}^{-3}\right)$ & $34(62)$ & $23(36)$ & $50(76)$ & $77(156)$ \\
\hline $\mathrm{SO}_{2}(\mathrm{ppbv})$ & 4.3 (12.9) & $2.0(4.4)$ & $2.6(5.4)$ & $4.4(9.5)$ \\
\hline $\mathrm{NO}_{2}(\mathrm{ppbv})$ & $3.7(7.3)$ & $6.2(12.1)$ & $6.2(12.7)$ & $6.1(9.9)$ \\
\hline Wind Speed $\left(\mathrm{m} \mathrm{s}^{-1}\right)$ & $13.5(16.0)$ & $9.5(16.1)$ & $6.6(10.2)$ & $5.0(7.7)$ \\
\hline
\end{tabular}

* Measurements are given for the average with the maximum in parentheses.

even though the " $\mathrm{O}_{3}$ night-PAN night" group concentrations were lower (Fig. 3). In addition, several days were classified as belonging to the " $\mathrm{O}_{3}$ night-PAN day" (marked by diamond) and " $\mathrm{O}_{3}$ day-PAN night" groups, but they showed less frequency and lower concentrations. These results indicate that the decoupling of PAN from $\mathrm{O}_{3}$ was primarily due to the elevated concentrations of $\mathrm{O}_{3}$ and PAN at night. While PAN reached the maximum during the day on 20 October and 5 November, their concentrations were increased from the previous day through the night. The four high PAN and $\mathrm{O}_{3}$ episodes identified in this study fall under the category of " $\mathrm{O}_{3}$ night-PAN night" or " $\mathrm{O}_{3}$ day-PAN day". These two cases will be further examined to identify the chemical and physical processes responsible for PAN being decoupled from $\mathrm{O}_{3}$, instead of being coupled with $\mathrm{PM}_{2.5}$. The overall characteristics of the four episodes are summarized in Table 1.

\subsection{Export of $\mathrm{O}_{3}$ from Asian continents (episodes 1 and} 2)

High $\mathrm{O}_{3}$ concentrations were encountered around midnight on three consecutive days from 31 October to 2 November (episode 1), during which $\mathrm{SO}_{2}$ reached its maximum concentration (Fig. 1). The backward trajectories of air masses revealed that air passed through the Beijing area during this period (Fig. 4). The strong wind $\left(13.5 \mathrm{~m} \mathrm{~s}^{-1}\right.$ on average) implies that it would take about a day for air mass leaving Beijing area to arrive at GCO. The recorded $\mathrm{O}_{3}$ maximum $(80.6 \mathrm{ppbv})$ was concurrent with the PAN maximum (0.9 ppbv) around midnight on 1 November (Fig. 1). All these results indicate that the air was heavily influenced by outflow from the Beijing area, as previously hypothesized (Lim et al., 2012), and that the nighttime enhancement of $\mathrm{O}_{3}$ and PAN with $\mathrm{SO}_{2}$ resulted from the fast transport of urban plumes from China.

In previous studies, the nighttime enhancement of $\mathrm{O}_{3}$ was observed at GCO (e.g., Lee et al., 2007) in association with pollutant-laden air coming from Beijing. Similarly, Banta et al. (1998) pointed out that the evening $\mathrm{O}_{3}$ maximum was

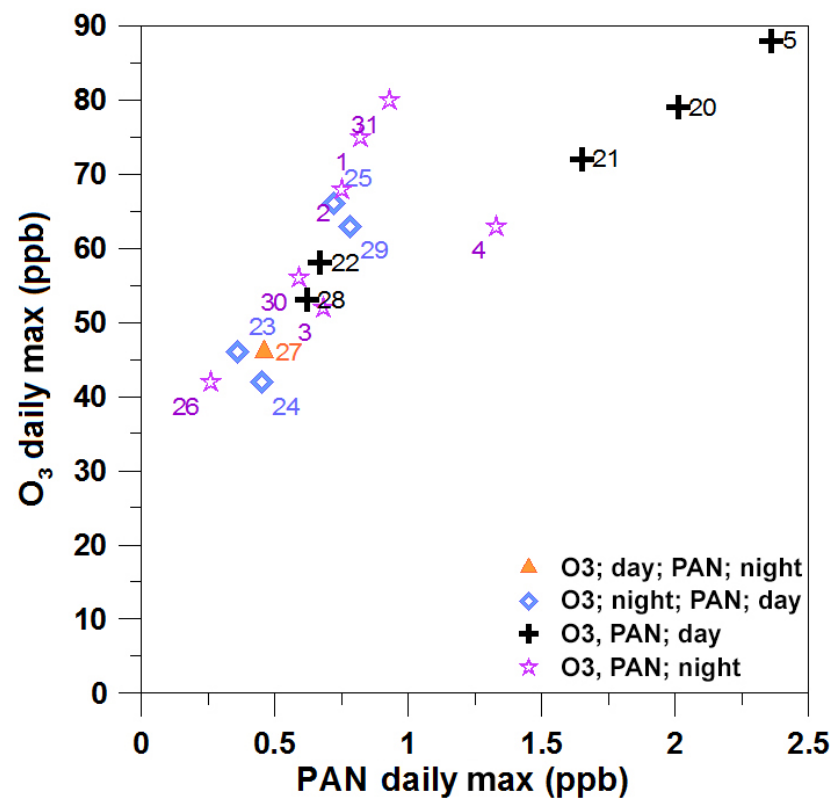

Figure 3. Comparison of $\mathrm{O}_{3}$ with the PAN daily maxima. The time when the daily maximum appears is classified as daytime (08:0018:00) and nighttime (the rest) based on the time of sunrise and sunset. Numerals indicate the days.

due to long-range transport of $\mathrm{O}_{3}$ from nearby urban areas. Wang et al. (2011) reported that the $\mathrm{O}_{3}$ lifetime was about two days in east China during the summer, which is sufficient for $\mathrm{O}_{3}$ to travel to GCO but not for PAN due to its short lifetime. Therefore, the nighttime maximum of $\mathrm{O}_{3}$ can be attributed to the export of $\mathrm{O}_{3}$ from megacities in China, causing PAN to be decoupled from $\mathrm{O}_{3}$. Because the overall correlation between $\mathrm{O}_{3}$ and PAN was the best with the highest $\Delta \mathrm{O}_{3} / \triangle \mathrm{PAN}$ among all cases discussed in this study (Fig. 5a), episode 1 likely represents an event of rapid transport from the Beijing area.

Another night maximum of $\mathrm{O}_{3}$ was recorded on 29 October. Note that $\mathrm{NO}_{x}$ was highly elevated with the lowest $\mathrm{SO}_{2}$ concentrations during 28-29 October (episode 2) (Fig. 1). In 
(a)

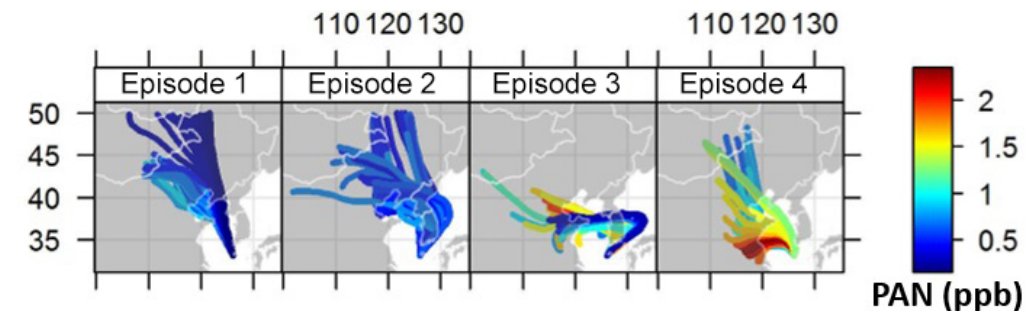

(b)

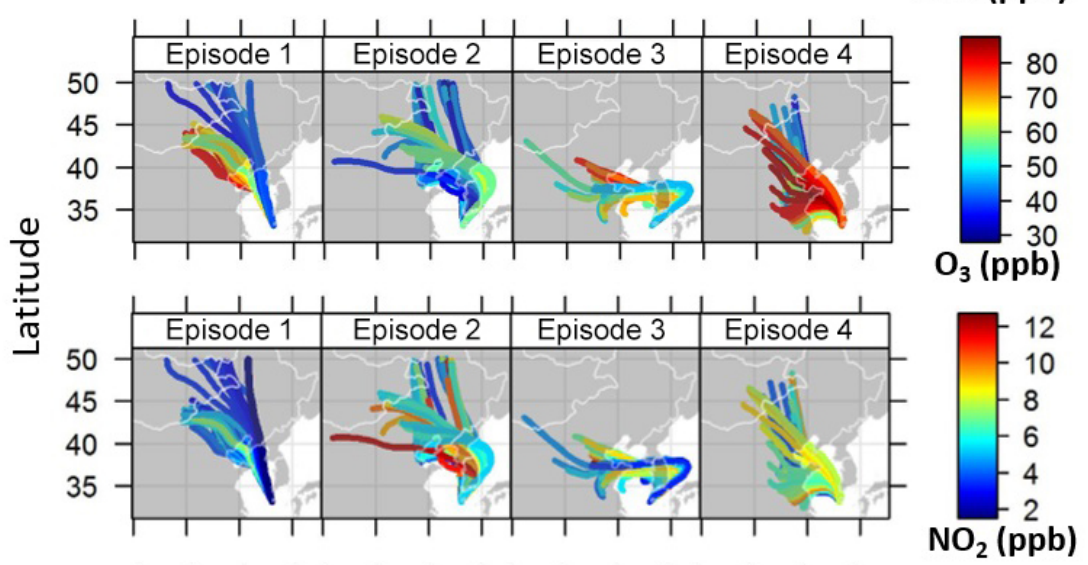

(d)

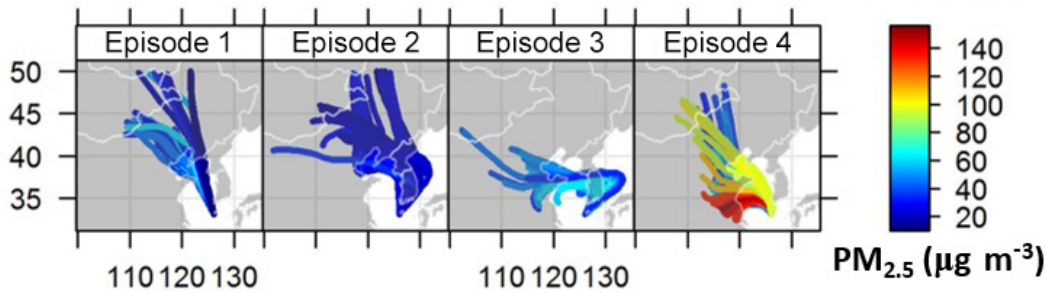

Longitude

(e)

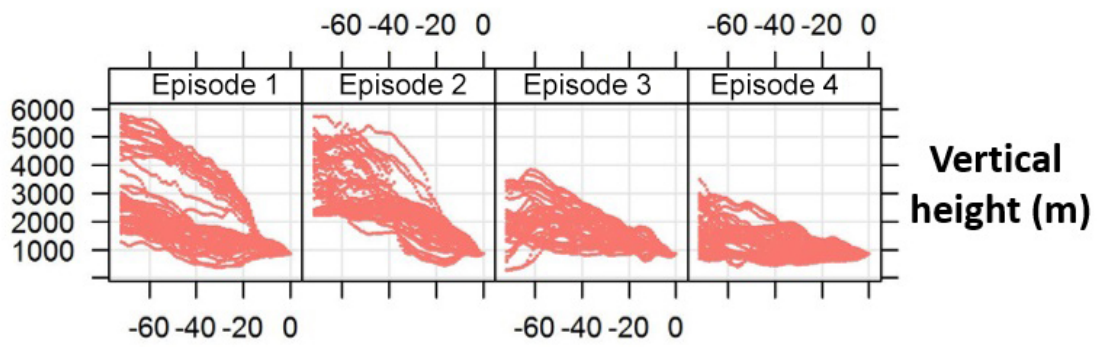

Hours

Figure 4. The three-day NOAA HYSPLIT backward trajectories of air masses for every $1 \mathrm{~h}$ observed at GCO during episode 1 (31 October2 November), episode 2 (28-29 October), episode 3 (20-21 October), and episode 4 (4-5 November). They are colored according to the level of (a) PAN, (b) $\mathrm{O}_{3}$, (c) $\mathrm{NO}_{2}$, and (d) $\mathrm{PM}_{2.5}$ at $\mathrm{GCO}$ at the time of the trajectory initialization. The trajectories north of $50^{\circ} \mathrm{N}$ are not shown. For these horizontal trajectories, (e) vertical heights are given.

episode $2, \mathrm{O}_{3}$ concentrations were much lower and poorly correlated with those of PAN, compared to episode 1. Instead, PAN was best correlated with $\mathrm{NO}_{2}$ with the highest $\Delta \mathrm{NO}_{2} / \triangle \mathrm{PAN}$ among all episodes (Fig. $5 \mathrm{a}, \mathrm{b}$ ). In this case, air masses passed through the Korean Peninsula, carrying low $\mathrm{O}_{3}$ being titrated by high $\mathrm{NO}_{x}$ (Brasseur et al., 1999; Jacobson, 2005). These two episodes illustrate the export of urban plumes in northeast Asia region, which are distinguished by the relative enhancement of reactive gases including $\mathrm{O}_{3}$,
PAN, and $\mathrm{NO}_{x}$, depending on the origin and aging of air masses.

\subsection{PAN enhancement upon the occurrence of haze (episodes 3 and 4)}

In this study, two haze events were observed in the very beginning (20-21 October; episode 3) and the end of the study period (4-5 November; episode 4). As the nighttime $\mathrm{O}_{3}$ peak 
(a)

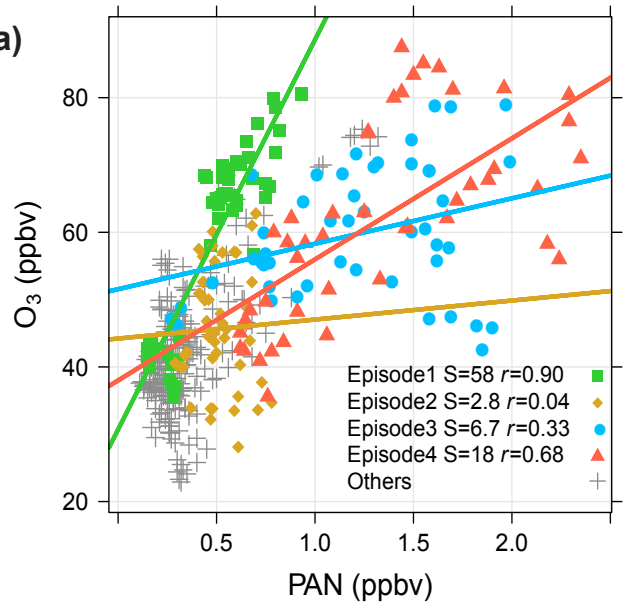

(c)

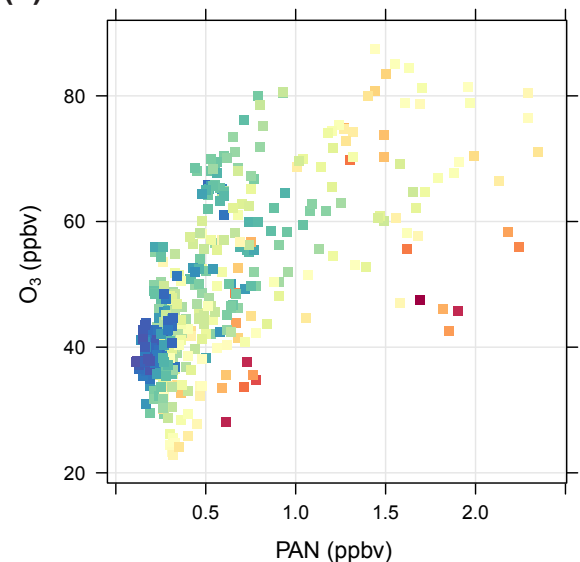

(b)

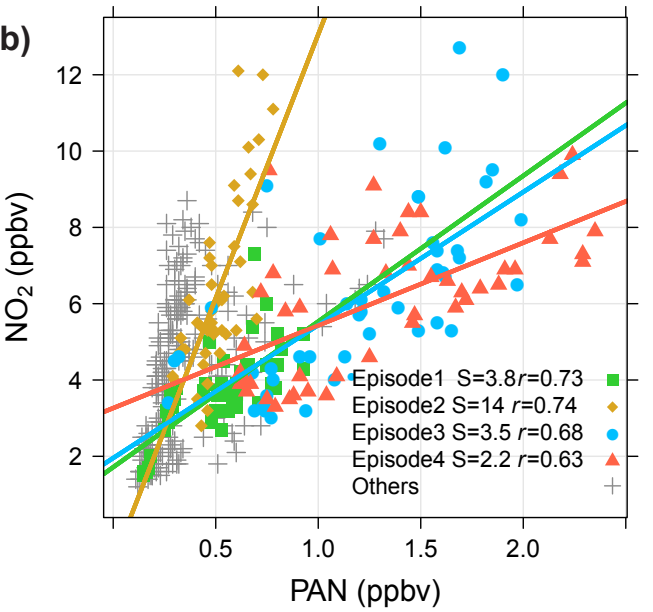

(d)

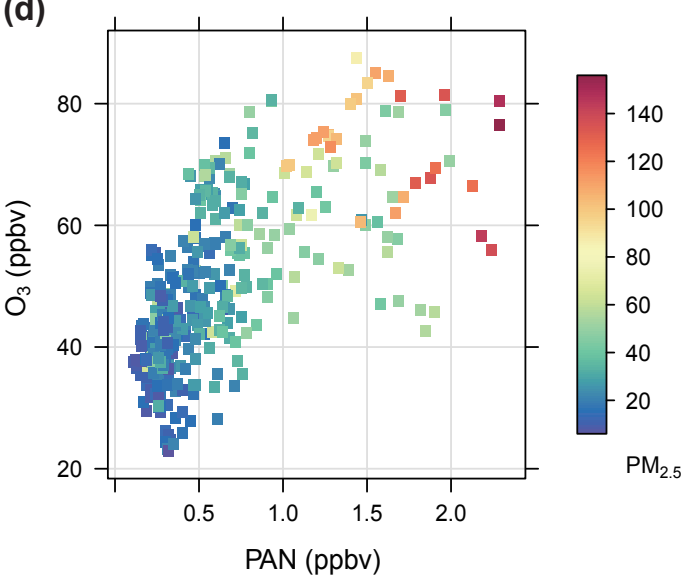

Figure 5. Correlations between (a) $\mathrm{PAN}$ and $\mathrm{O}_{3}$ and (b) $\mathrm{PAN}$ and $\mathrm{NO}_{2}$ with linear regression line for each episode. Correlations between $\mathrm{O}_{3}$ and PAN were color-coded by the level of (c) $\mathrm{NO}_{2}$ and (d) $\mathrm{PM}_{2.5}$.

was attributed to the transport from nearby urban areas to Jeju Island, the two haze episodes were also observed in association with continental outflows. The first haze event occurred on 18 October and persisted until 21 October, during which $\mathrm{O}_{3}$ concentrations were gradually elevated. A second peak was recorded around midnight of 19 and 20 October, and the maximum was reached in the afternoon of 20 October (Figs. 1 and 3). In this episode, the maximum concentrations of $\mathrm{O}_{3}$ and PAN were 78.9 and $2.0 \mathrm{ppbv}$, respectively, on 20 October, when the highest $\mathrm{NO}_{2}$ concentration (12.7 ppbv) was observed under low wind speed $\left(6.6 \mathrm{~m} \mathrm{~s}^{-1}\right.$ daily average). The air mass trajectories suggest the influence of the Korean Peninsula, particularly the Seoul metropolitan area, in addition to east China (Fig. 4).

In the second haze event (episode 4), an air mass was slowly transported from east China, including the Jiangsu province, under stagnant conditions which were developed by an anticyclone system (Fig. 4). We measured the highest concentrations of all aerosol species including the $\mathrm{PM}_{2.5}$ mass as well as PAN and $\mathrm{O}_{3}$, which were $156 \mu \mathrm{g} \mathrm{m}^{-3}$, $2.4 \mathrm{ppbv}$ and $87.5 \mathrm{ppbv}$, respectively. Other reactive gases such as $\mathrm{CO}, \mathrm{SO}_{2}$, and $\mathrm{NO}_{2}$ were also highly elevated. Note that PAN and $\mathrm{O}_{3}$ gradually increased through the night, leading to a nighttime maximum of both species on 4 November. It is likely that the pre-formed PAN and $\mathrm{O}_{3}$ were continuously transported into Gosan at night.

PAN is formed through the reaction of the peroxyacetyl radical and nitrogen dioxide (Eq. 1) and decomposed at high temperature (Eq. 2), returning these radicals. Unless the NO concentration is high (Eq. 3), the peroxyacetyl radical recombines with $\mathrm{NO}_{2}$, producing PAN. Thus, the total lifetime of PAN depends on the $\mathrm{NO}_{2} / \mathrm{NO}$ ratio and temperature (Eq. 4) (Brasseur et al., 1999).

$$
\begin{aligned}
& \mathrm{CH}_{3} \mathrm{C}(\mathrm{O}) \mathrm{O}_{2}+\mathrm{NO}_{2}+\mathrm{M} \rightarrow \mathrm{PAN}+\mathrm{M}, \\
& \mathrm{PAN} \rightarrow \mathrm{CH}_{3} \mathrm{C}(\mathrm{O}) \mathrm{O}_{2}+\mathrm{NO}_{2}, \\
& \mathrm{CH}_{3} \mathrm{C}(\mathrm{O}) \mathrm{O}_{2}+\mathrm{NO} \rightarrow \mathrm{CH}_{3} \mathrm{CO}_{2}+\mathrm{NO}_{2}, \\
& T_{\text {eff }}=T_{\mathrm{d}}\left(1+\frac{k_{1}\left[\mathrm{NO}_{2}\right]}{k_{2}[\mathrm{NO}]}\right)\left[\mathrm{s}^{-1}\right],
\end{aligned}
$$

where $T_{\mathrm{d}}$ and $T_{\text {eff }}$ indicate the lifetime against decomposition and the effective lifetime of PAN (Brasseur et al., 1999). 

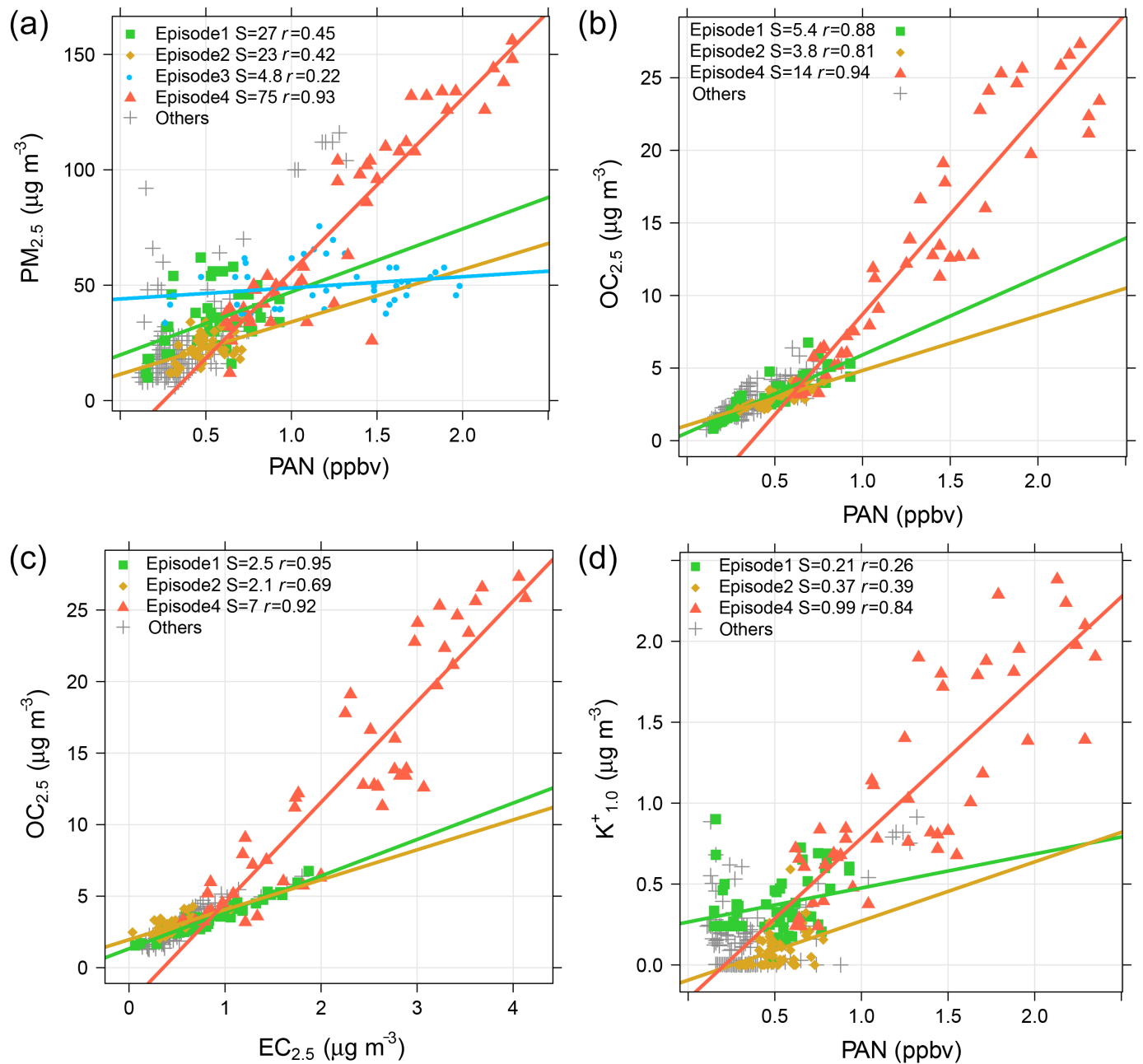

Figure 6. Correlations among PAN, the $\mathrm{K}^{+}$ion of $\mathrm{PM}_{1.0}$, and carbonaceous components of $\mathrm{PM}_{2.5}$ for four episodes: (a) PAN and PM 2.5 mass, (b) PAN and $\mathrm{PM}_{2.5}$ OC, (c) $\mathrm{PM}_{2.5} \mathrm{EC}$ and $\mathrm{OC}$, and (d) PAN and $\mathrm{PM}_{1.0} \mathrm{~K}^{+}$. The lines represent the linear regression for each episode.

The effective lifetime of PAN was estimated through Eq. (4) using the rate constants proposed by Brasseur et al. (1999), Jacobson (2005), and Maricq and Szente (1996).

During the haze event, NO was close to the detection limit, while $\mathrm{NO}_{2}$ was greatly enhanced. Owing to the high $\mathrm{NO}_{2} / \mathrm{NO}$ ratio, the effective lifetime of PAN increased by $57 \pm 14$ times; this possibly contributed to the gradual increase in PAN through the night on 4 November. For this estimation, the PAN concentration was subtracted from the measured $\mathrm{NO}_{2}$ concentration, considering the positive artifact from the molybdenum converter in the $\mathrm{NO}_{2}$ measurement. Fischer et al. (2014) also reported that, at night, PAN can be produced from the reaction of acetaldehyde with the nitrate radical.

Besides $\mathrm{PM}_{2.5}$ mass, PAN was also well correlated with $\mathrm{PM}_{2.5}$ OC and EC not only during this haze episode but also during the entire measurement period (Fig. $6 a$ and $b$ ). Furthermore, the enhancement of PAN was concurrent with that of $\mathrm{OC}$ and $\mathrm{K}^{+}$, resulting in excellent correlation be- tween them (Fig. $6 \mathrm{~b}$ and d). In fact, the $\Delta \mathrm{OC} / \Delta \mathrm{EC}$ ratio of episode 4 was much higher (7) than those of the other episodes $(\sim 2.5)$ (Fig. 6c). The fraction of $\mathrm{PM}_{2.5}$ against $\mathrm{PM}_{10}$ was also the highest in this episode, indicating a significant contribution of secondary aerosols. These observations suggest that air masses were affected by biomass combustion (e.g., Ram et al., 2008, 2012; Saarikoski et al., 2008).

According to previous studies, PAN can be produced in plumes through biomass combustion (Alvarado et al., 2010; Coheur et al., 2007; X. Liu et al., 2016; Tereszchuk et al., 2013). In northeast China, open burnings related to agricultural activities frequently occur during the spring and fall (Duan et al., 2004; Yang et al., 2005). Kudo et al. (2014) also reported that, after the burning of crop residue in the Yangtze region, the levels of oxygenated VOCs were elevated together with $\mathrm{NO}_{x}$. In addition, biofuel is used for cooking and heating and as an energy source in China's industry (Cao et al., 2006). 
(a)

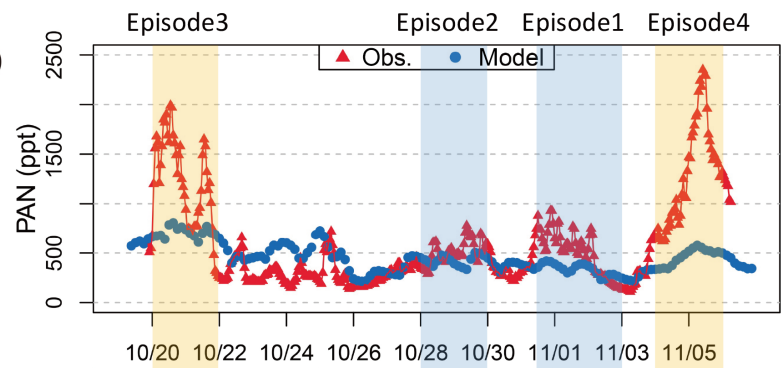

(b)

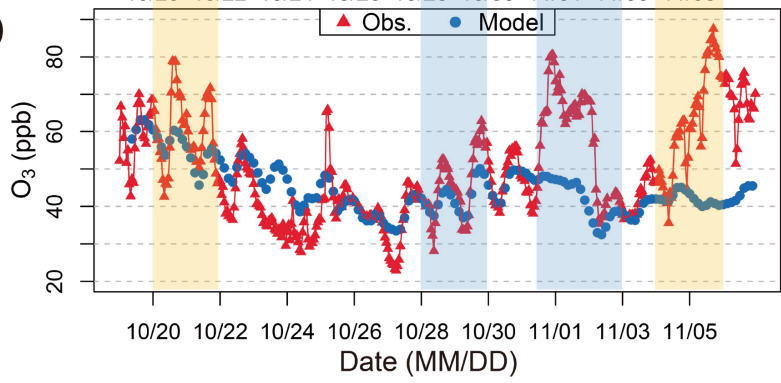

Figure 7. Comparison between the observed and calculated (a) PAN and (b) $\mathrm{O}_{3}$ concentrations by CAM-chem model. Time is given in local time and the four episodes are shaded.

Therefore, PAN is likely to increase when haze occurs and fine aerosols are transformed as air masses carrying combustion emissions are slowly transported from China over the Yellow Sea. Additionally, the results of this study imply that PAN can be used as a robust tracer for continental outflows in northeast Asia, to identify transport- and chemicaltransformation-dominant regimes. In a transport-dominant regime, $\mathrm{O}_{3}$ export was distinguished by the highest levels of primary gaseous species such as $\mathrm{SO}_{2}$ and relatively low levels of PAN. In contrast, fine aerosol species were enhanced in a chemical transformation regime, leading to haze events with relatively more enhanced PAN compared to $\mathrm{O}_{3}$.

Finally, the measured $\mathrm{O}_{3}$ and PAN concentrations were compared to results from a global chemistry model CAMchem. In the model simulation, $\mathrm{O}_{3}$ and PAN were highly underestimated during the episodes observed in Chinese outflows, although the variation around the average level of $\mathrm{O}_{3}$ and PAN was well captured (Fig. 7). The elevated PAN concentration was underestimated in the model (20-21 October and 4-5 November), especially when air was impacted by biomass combustion. The timing of the $\mathrm{O}_{3}$ diurnal variability was captured by the model, although the magnitude of the variation was underestimated. These results reveal that the current understanding of Chinese outflow is still not sufficient, thereby causing uncertainty in estimating its effect on air quality in the northwestern Pacific Rim.

\section{Conclusions}

The first measurements of PAN, reactive gases, and aerosol species were conducted at GCO during 19 October to 6 November 2010. The average concentration of PAN was $0.6 \mathrm{ppbv}$ with a maximum of $2.4 \mathrm{ppbv}$, which was lower than those in major cities in East Asia but much higher than the background concentrations in other regions. Although the hourly concentrations of PAN and $\mathrm{O}_{3}$ were well correlated $(\gamma=0.67)$, the comparison of the daily maxima of PAN and $\mathrm{O}_{3}$ highlighted that they were not proportionally enhanced. That is, either PAN was relatively more elevated than $\mathrm{O}_{3}$ or the highest $\mathrm{O}_{3}$ was associated with low levels of PAN. Unexpectedly, both PAN and $\mathrm{O}_{3}$ often reached their maxima at night. In this study, these high concentrations were all encountered in association with continental outflows, where PAN was decoupled from $\mathrm{O}_{3}$ and better correlated with the $\mathrm{PM}_{2.5}$ mass $(\gamma=0.79)$ than with $\mathrm{O}_{3}$. Thus, two high $-\mathrm{O}_{3}$ and two high-PAN events were the most clearly distinguished and investigated in detail.

During the $\mathrm{O}_{3}$ episodes, both $\mathrm{O}_{3}$ and PAN concentrations reached their maximum values at night. In episode 1 (31 October to 2 November), the $\mathrm{O}_{3}$ concentration was increased to $80.6 \mathrm{ppbv}$, with a high $\mathrm{SO}_{2}$ concentration under strong wind. This was typical for the Beijing plume observed in the study region. In comparison, $\mathrm{NO}_{2}$ was greatly increased in episode 2 (28-29 October) when the air masses were affected by urban emissions from Korean Peninsula. Although the maximum $\mathrm{O}_{3}$ level was lower during episode 2, these two cases demonstrated well how $\mathrm{O}_{3}$ was exported from the East Asian continent.

The remaining two episodes were highlighted by enhanced PAN concentrations and characterized by haze occurrence. During episode 3 (20-21 October), PAN and $\mathrm{O}_{3}$ concentrations increased by up to 2.0 and $78.9 \mathrm{ppbv}$, respectively, with high $\mathrm{NO}_{x}$ levels, probably influenced by emissions from Korea. Episode 4 (4-5 November) was characterized by the highest concentrations of almost all measured species, including $\mathrm{PAN}, \mathrm{O}_{3}, \mathrm{PM}_{2.5}$ mass, and $\mathrm{PM}_{1.0}$ species; the maximum recorded concentrations of $\mathrm{PAN}, \mathrm{O}_{3}$, and $\mathrm{PM}_{2.5}$ mass during this interval were $2.4 \mathrm{ppbv}, 87.5 \mathrm{ppbv}$, and $156 \mu \mathrm{g} \mathrm{m}^{-3}$, respectively. Note that, along with $\mathrm{PM}_{2.5}$ and $\mathrm{O}_{3}$, PAN gradually increased through the night. In this episode, an air mass was slowly transported from eastern China. With depleted NO, the effective lifetime of PAN was greatly extended. In addition, PAN concentration showed good correlation with $\mathrm{OC}, \mathrm{EC}$, and $\mathrm{K}^{+}$; in fact, the correlation of PAN with $\mathrm{K}^{+}$was comparable to that of $\mathrm{OC}$ with $\mathrm{K}^{+}$. These results, in conjunction with the high OC / EC (7), imply that the observed haze was mainly caused by the emissions produced by biomass combustion. These results suggest that PAN is a useful tool for distinguishing between continental outflows that were typically observed in northeast Asia. 
The comparison between the measured and calculated concentrations using the CAM-chem-HTAP2 model showed that the model underestimated the $\mathrm{O}_{3}$ and PAN levels in Chinese outflows, particularly for haze incidence. These results reveal that Chinese outflows are still poorly understood and not well captured in the model.

Data availability. The data presented in this article are available from the corresponding author upon request.

Competing interests. The authors declare that they have no conflict of interest.

Acknowledgements. This study was funded by the Korea Meteorological Administration Research and Development Program under Grant KMIPA 2015-6020. The National Center for Atmospheric Research is funded by the National Science Foundation. The authors gratefully acknowledge the NOAA Air Resources Laboratory (ARL) for the provision of the HYSPLIT transport and dispersion model and the READY website (http://www.ready.noaa.gov) used in this publication.

Edited by: James Roberts

Reviewed by: two anonymous referees

\section{References}

Akimoto, H.: Global air quality and pollution, Science, 302, 17161719, https://doi.org/10.1126/science.1092666, 2003.

Alvarado, M. J., Logan, J. A., Mao, J., Apel, E., Riemer, D., Blake, D., Cohen, R. C., Min, K.-E., Perring, A. E., Browne, E. C., Wooldridge, P. J., Diskin, G. S., Sachse, G. W., Fuelberg, H., Sessions, W. R., Harrigan, D. L., Huey, G., Liao, J., Case-Hanks, A., Jimenez, J. L., Cubison, M. J., Vay, S. A., Weinheimer, A. J., Knapp, D. J., Montzka, D. D., Flocke, F. M., Pollack, I. B., Wennberg, P. O., Kurten, A., Crounse, J., Clair, J. M. St., Wisthaler, A., Mikoviny, T., Yantosca, R. M., Carouge, C. C., and Le Sager, P.: Nitrogen oxides and PAN in plumes from boreal fires during ARCTAS-B and their impact on ozone: an integrated analysis of aircraft and satellite observations, Atmos. Chem. Phys., 10, 9739-9760, https://doi.org/10.5194/acp10-9739-2010, 2010.

Aneja, V. P., Hartsell, B. E., Kim, D. S., and Grosjean, D.: Peroxyacetyl nitrate in Atlanta, Georgia: Comparison and analysis of ambient data for suburban and downtown locations, J. Air Waste Manage., 49, 177-184, https://doi.org/10.1080/10473289.1999.10463786, 1999.

Banta, R. M., Senff, C. J., White, A. B., Trainer, M., McNider, R. T., Valente, R. J., Mayor, S. D., Alvarez, R. J., Hardesty, R. M., Parrish, D., and Fehsenfeld, F. C.: Daytime buildup and nighttime transport of urban ozone in the boundary layer during a stagnation episode, J. Geophys. Res.-Atmos., 103, 22519-22544, https://doi.org/10.1029/98jd01020, 1998.
Beine, H. J., Jaffe, D. A., Herring, J. A., Kelley, J. A., Krognes, T., and Stordal, F.: High-latitude springtime photochemistry: 1. NOx, PAN and ozone relationships, J. Atmos. Chem., 27, 127153, https://doi.org/10.1023/a:1005869900567, 1997.

Bertram, T. H., Perring, A. E., Wooldridge, P. J., Dibb, J., Avery, M. A., and Cohen, R. C.: On the export of reactive nitrogen from Asia: $\mathrm{NO}_{x}$ partitioning and effects on ozone, Atmos. Chem. Phys., 13, 4617-4630, https://doi.org/10.5194/acp13-4617-2013, 2013.

Brasseur, G. P., Orlando, J. J., and Tyndall, G. S.: Atmospheric chemistry and global change, Oxford University Press, New York, 235-347, 1999.

Cao, G., Zhang, X., and Zheng, F.: Inventory of black carbon and organic carbon emissions from China, Atmos. Environ., 40, 65166527, https://doi.org/10.1016/j.atmosenv.2006.05.070, 2006.

Coheur, P.-F., Herbin, H., Clerbaux, C., Hurtmans, D., Wespes, C., Carleer, M., Turquety, S., Rinsland, C. P., Remedios, J., Hauglustaine, D., Boone, C. D., and Bernath, P. F.: ACE-FTS observation of a young biomass burning plume: first reported measurements of $\mathrm{C}_{2} \mathrm{H}_{4}, \mathrm{C}_{3} \mathrm{H}_{6} \mathrm{O}, \mathrm{H}_{2} \mathrm{CO}$ and PAN by infrared occultation from space, Atmos. Chem. Phys., 7, 5437-5446, https://doi.org/10.5194/acp-7-5437-2007, 2007.

Draxler, R. R. and Rolph, G. D.: HYSPLIT (HYbrid Single-Particle Lagrangian Integrated Trajectory) Model, NOAA Air Resources Laboratory, Silver Spring, MD, available at: http://ready.arl.noaa. gov/HYSPLIT.php, 2012.

Duan, F., Liu, X., Yu, T., and Cachier, H.: Identification and estimate of biomass burning contribution to the urban aerosol organic carbon concentrations in Beijing, Atmos. Environ., 38, 1275-1282, https://doi.org/10.1016/j.atmosenv.2003.11.037, 2004.

Fischer, E. V., Jaffe, D. A., Reidmiller, D. R., and Jaeglé, L.: Meteorological controls on observed peroxyacetyl nitrate at Mount Bachelor during the spring of 2008, J. Geophys. Res., 115, D03302, https://doi.org/10.1029/2009jd012776, 2010.

Fischer, E. V., Jaffe, D. A., and Weatherhead, E. C.: Free tropospheric peroxyacetyl nitrate (PAN) and ozone at Mount Bachelor: potential causes of variability and timescale for trend detection, Atmos. Chem. Phys., 11, 5641-5654, https://doi.org/10.5194/acp-11-5641-2011, 2011.

Fischer, E. V., Jacob, D. J., Yantosca, R. M., Sulprizio, M. P., Millet, D. B., Mao, J., Paulot, F., Singh, H. B., Roiger, A., Ries, L., Talbot, R. W., Dzepina, K., and Pandey Deolal, S.: Atmospheric peroxyacetyl nitrate (PAN): a global budget and source attribution, Atmos. Chem. Phys., 14, 2679-2698, https://doi.org/10.5194/acp-14-2679-2014, 2014.

Gaffney, J. S., Fajer, R., and Senum, G. I.: An improved procedure for high purity gaseous peroxyacyl nitrate production: Use of heavy lipid solvents, Atmos. Environ., 18, 215-218, https://doi.org/10.1016/0004-6981(84)90245-2, 1984.

Gaffney, J. S., Bornick, R. M., Chen, Y. H., and Marley, N. A.: Capillary gas chromatographic analysis of nitrogen dioxide and pans with luminol chemiluminescent detection, Atmos. Environ., 32, 1445-1454, https://doi.org/10.1016/S1352-2310(97)00098$8,1998$.

Gaffney, J. S., Marley, N. A., Cunningham, M. M., and Doskey, P. V.: Measurements of peroxyacyl nitrates (PANs) in Mexico City: implications for megacity air quality impacts on regional scales, Atmos. Environ., 33, 5003-5012, https://doi.org/10.1016/S13522310(99)00263-0, 1999. 
Gallagher, M. S., Carsey, T. P., and Farmer, M. L.: Peroxyacetyl nitrate in the North Atlantic marine boundary layer, Global Biogeochem. Cy., 4, 297-308, https://doi.org/10.1029/GB004i003p00297, 1990.

Gregory, G. L.: An intercomparison of airborne PAN measurements, J. Geophys. Res., 95, 10077-10087, https://doi.org/10.1029/JD095iD07p10077, 1990.

Grosjean, E., Grosjean, D., Woodhouse, L. F., and Yang, Y.-J.: Peroxyacetyl nitrate and peroxypropionyl nitrate in Porto Alegre, Brazil, Atmos. Environ., 36, 2405-2419, https://doi.org/10.1016/S1352-2310(01)00541-6, 2002.

Gu, D., Wang, Y., Smeltzer, C., and Liu, Z.: Reduction in NOx Emission Trends over China: Regional and Seasonal Variations, Environ. Sci. Technol., 47, 12912-12919, https://doi.org/10.1021/es401727e, 2013.

Hansel, A. and Wisthaler, A.: A method for real-time detection of PAN, PPN and MPAN in ambient air, Geophys. Res. Lett., 27, 895-898, https://doi.org/10.1029/1999g1010989, 2000.

Jacob, D. J.: Introduction to atmospheric chemistry, Princeton University Press, 199-231, 1999.

Jacob, D. J.: Heterogeneous chemistry and tropospheric ozone, Atmos. Environ., 34, 2131-2159, https://doi.org/10.1016/s13522310(99)00462-8, 2000.

Jacobson, M. Z.: Fundamentals of atmospheric modeling, 2nd Edn., Cambridge, UK, 731-738, 2005.

Jaffe, D. A., Thornton, J., Wolfe, G., Reidmiller, D., Fischer, E. V., Jacob, D. J., Zhang, L., Cohen, R., Singh, H., Weinheimer, A., and Flocke, F.: Can we detect an Influence over North America from Increasing Asian $\mathrm{NO}_{x}$ Emissions?, EOS T. Am. Geophys. Un., 88, 2007.

Janssens-Maenhout, G., Crippa, M., Guizzardi, D., Dentener, F., Muntean, M., Pouliot, G., Keating, T., Zhang, Q., Kurokawa, J., Wankmüller, R., Denier van der Gon, H., Kuenen, J. J. P., Klimont, Z., Frost, G., Darras, S., Koffi, B., and Li, M.: HTAP_v2.2: a mosaic of regional and global emission grid maps for 2008 and 2010 to study hemispheric transport of air pollution, Atmos. Chem. Phys., 15, 11411-11432, https://doi.org/10.5194/acp-15-11411-2015, 2015.

Kanaya, Y., Tanimoto, H., Matsumoto, J., Furutani, H., Hashimoto, S., Komazaki, Y., Tanaka, S., Yokouchi, Y., Kato, S., Kajii, Y., and Akimoto, H.: Diurnal variations in $\mathrm{H}_{2} \mathrm{O}_{2}, \mathrm{O}_{3}, \mathrm{PAN}, \mathrm{HNO}_{3}$ and aldehyde concentrations and $\mathrm{NO} / \mathrm{NO}_{2}$ ratios at Rishiri Island, Japan: Potential influence from iodine chemistry, Sci. Total Envir., 376, 185-197, https://doi.org/10.1016/j.scitotenv.2007.01.073, 2007.

Kenley, R. A. and Hendry, D. G.: Generation of peroxy radicals from peroxynitrates $\left(\mathrm{ROONO}_{2}\right)$, Decomposition of peroxybenzoyl nitrate (PBzN), J. Am. Chem. Soc., 104, 220-224, https://doi.org/10.1021/ja00365a040, 1982.

Kourtidis, K. A., Fabian, P., Zerefos, C., and RappenglÜCk, B.: Peroxyacetyl nitrate (PAN), peroxypropionyl nitrate (PPN) and PAN/ozone ratio measurements at three sites in Germany, Tellus B, 45, 442-457, https://doi.org/10.1034/j.16000889.1993.t01-3-00004.x, 1993.

Krotkov, N. A., McLinden, C. A., Li, C., Lamsal, L. N., Celarier, E. A., Marchenko, S. V., Swartz, W. H., Bucsela, E. J., Joiner, J., Duncan, B. N., Boersma, K. F., Veefkind, J. P., Levelt, P. F., Fioletov, V. E., Dickerson, R. R., He, H., Lu, Z., and Streets, D. G.: Aura OMI observations of regional $\mathrm{SO}_{2}$ and $\mathrm{NO}_{2}$ pollu- tion changes from 2005 to 2015, Atmos. Chem. Phys., 16, 46054629, https://doi.org/10.5194/acp-16-4605-2016, 2016.

Kudo, S., Tanimoto, H., Inomata, S., Saito, S., Pan, X., Kanaya, Y., Taketani, F., Wang, Z., Chen, H., Dong, H., Zhang, M., and Yamaji, K.: Emissions of nonmethane volatile organic compounds from open crop residue burning in the Yangtze River Delta region, China, J. Geophys. Res., 119, 7684-7698, https://doi.org/10.1002/2013JD021044, 2014.

LaFranchi, B. W., Wolfe, G. M., Thornton, J. A., Harrold, S. A., Browne, E. C., Min, K. E., Wooldridge, P. J., Gilman, J. B., Kuster, W. C., Goldan, P. D., de Gouw, J. A., McKay, M., Goldstein, A. H., Ren, X., Mao, J., and Cohen, R. C.: Closing the peroxy acetyl nitrate budget: observations of acyl peroxy nitrates (PAN, PPN, and MPAN) during BEARPEX 2007, Atmos. Chem. Phys., 9, 7623-7641, https://doi.org/10.5194/acp-9-7623-2009, 2009.

Lamarque, J.-F., Emmons, L. K., Hess, P. G., Kinnison, D. E., Tilmes, S., Vitt, F., Heald, C. L., Holland, E. A., Lauritzen, P. H., Neu, J., Orlando, J. J., Rasch, P. J., and Tyndall, G. K.: CAM-chem: description and evaluation of interactive atmospheric chemistry in the Community Earth System Model, Geosci. Model Dev., 5, 369-411, https://doi.org/10.5194/gmd-5369-2012, 2012.

Lee, G., Jang, Y., Lee, H., Han, J.-S., Kim, K.-R., and Lee, M.: Characteristic behavior of peroxyacetyl nitrate (PAN) in Seoul megacity, Korea, Chemosphere, 73, 619-628, https://doi.org/10.1016/j.chemosphere.2008.05.060, 2008.

Lee, G., Choi, H.-S., Lee, T., Choi, J., Park, J. S., and Ahn, J. Y.: Variations of regional background peroxyacetyl nitrate in marine boundary layer over Baengyeong Island, South Korea, Atmos. Environ., 61, 533-541, https://doi.org/10.1016/j.atmosenv.2012.07.075, 2012.

Lee, M., Song, M., Moon, K. J., Han, J. S., Lee, G., and Kim, K.R.: Origins and chemical characteristics of fine aerosols during the northeastern Asia regional experiment (Atmospheric Brown Cloud-East Asia Regional Experiment 2005), J. Geophys. Res., 112, D22S29, https://doi.org/10.1029/2006jd008210, 2007.

Lim, S., Lee, M., Lee, G., Kim, S., Yoon, S., and Kang, K.: Ionic and carbonaceous compositions of $\mathrm{PM}_{10}, \mathrm{PM}_{2.5}$ and $\mathrm{PM}_{1.0}$ at Gosan ABC Superstation and their ratios as source signature, Atmos. Chem. Phys., 12, 2007-2024, https://doi.org/10.5194/acp12-2007-2012, 2012.

Liu, F., Zhang, Q., A., van der A, R. J., Zheng, B., Tong, D., Yan, L., Zheng, Y., and He, K.: Recent reduction in $\mathrm{NO}_{x}$ emissions over China: synthesis of satellite observations and emission inventories, Environ. Res. Lett., 11, 114002, https://doi.org/10.1088/1748-9326/11/11/114002, 2016.

Liu, Z., Wang, Y., Gu, D., Zhao, C., Huey, L. G., Stickel, R., Liao, J., Shao, M., Zhu, T., Zeng, L., Liu, S.-C., Chang, C.-C., Amoroso, A., and Costabile, F.: Evidence of reactive aromatics as a major source of peroxy acetyl nitrate over China, Environ. Sci. Technol., 44, 7017-7022, https://doi.org/10.1021/es1007966, 2010.

Liu, X., Zhang, Y., Huey, L. G., Yokelson, R. J., Wang, Y., Jimenez, J. L., Campuzano-Jost, P., Beyersdorf, A. J., Blake, D. R., Choi, Y., St. Clair, J. M., Crounse, J. D., Day, D. A., Diskin, G. S., Fried, A., Hall, S. R., Hanisco, T. F., King, L. E., Meinardi, S., Mikoviny, T., Palm, B. B., Peischl, J., Perring, A. E., Pollack, I. B., Ryerson, T. B., Sachse, G., Schwarz, J. P., Simpson, I. J., Tanner, D. J., Thornhill, K. L., Ullmann, K., Weber, R. J., Wennberg, 
P. O., Wisthaler, A., Wolfe, G. M., and Ziemba, L. D.: Agricultural fires in the southeastern U.S. during SEAC4RS: Emissions of trace gases and particles and evolution of ozone, reactive nitrogen, and organic aerosol, J. Geophys, Res.-Atmos., 121, 73837414, https://doi.org/10.1002/2016JD025040, 2016.

Maricq, M. M. and Szente, J. J.: Temperature-dependent study of the $\mathrm{CH}_{3} \mathrm{C}(\mathrm{O}) \mathrm{O}_{2}+\mathrm{NO}$ reaction, J. Phys. Chem., 100, 1238012385, https://doi.org/10.1021/jp960792c, 1996.

Marley, N. A., Gaffney, J. S., White, R. V., Rodriguez-Cuadra, L., Herndon, S. E., Dunlea, E., Volkamer, R. M., Molina, L. T., and Molina, M. J.: Fast gas chromatography with luminol chemiluminescence detection for the simultaneous determination of nitrogen dioxide and peroxyacetyl nitrate in the atmosphere, Rev. Sci. Instr., 75, 4595-4605, https://doi.org/10.1063/1.1805271, 2004.

Mills, G. P., Sturges, W. T., Salmon, R. A., Bauguitte, S. J.-B., Read, K. A., and Bandy, B. J.: Seasonal variation of peroxyacetylnitrate (PAN) in coastal Antarctica measured with a new instrument for the detection of sub-part per trillion mixing ratios of PAN, Atmos. Chem. Phys., 7, 4589-4599, https://doi.org/10.5194/acp-74589-2007, 2007.

Muller, K. P. and Rudolph, J.: Measurements of peroxyacetylnitrate in the marine boundary layer over the Atlantic, J. Atmos. Chem., 15, 361-367, https://doi.org/10.1007/BF00115405, 1992.

Nielsen, T., Samuelsson, U., Grennfelt, P., and Thomsen, E. L.: Peroxyacetyl nitrate in long-range transported polluted air, Nature, 293, 553-555, https://doi.org/10.1038/293553a0, 1981.

NIER: Annual Report of Ambient Air Quality in Korea, National Institute of Environmental Research, Inchon, Korea, 350 pp., 2016a (in Korean).

NIER: Guidelines for installation and operation of air pollution monitoring network, National Institute of Environmental Research, Inchon, Korea, 427 pp., 2016b (in Korean).

Ohara, T., Akimoto, H., Kurokawa, J., Horii, N., Yamaji, K., Yan, X., and Hayasaka, T.: An Asian emission inventory of anthropogenic emission sources for the period 1980-2020, Atmos. Chem. Phys., 7, 4419-4444, https://doi.org/10.5194/acp-7-44192007, 2007.

Ram, K., Sarin, M. M., and Hegde, P.: Atmospheric abundances of primary and secondary carbonaceous species at two high-altitude sites in India: Sources and temporal variability, Atmos. Environ., 42, 6785-6796, https://doi.org/10.1016/j.atmosenv.2008.05.031, 2008.

Ram, K., Sarin, M. M., and Tripathi, S. N.: Temporal trends in atmospheric $\mathrm{PM}_{2.5}, \mathrm{PM}_{10}$, elemental carbon, organic carbon, water-soluble organic carbon, and optical properties: Impact of biomass burning emissions in the Indo-Gangetic Plain, Environ. Sci. Technol., 46, 686-695, https://doi.org/10.1021/es202857w, 2012.

Randerson, J. T., van der Werf, G. R., Giglio, L., Collatz, G. J., and Kasibhatla, P. S.: Global Fire Emissions Database, Version 3 (GFEDv3.1), Data set, Oak Ridge National Laboratory Distributed Active Archive Center, Oak Ridge, Tennessee, USA, https://doi.org/10.3334/ORNLDAAC/1191, 2013.

Ridley, B. A., Shetter, J. D., Gandrud, B. W., Salas, L. J., Singh, H. B., Carroll, M. A., Hubler, G., Albritton, D. L., Hastie, D. R., Schiff, H. I., Mackay, G. I., Karechi, D. R., Davis, D. D., Bradshaw, J. D., Rodgers, M. O., Sandholm, S. T., Torres, A. L., Condon, E. P., Gregory, G. L., and Beck, S. M.: Ratios of peroxyacetyl nitrate to active nitrogen observed dur- ing aircraft flights over the Eastern Pacific Oceans and continental United-States, J. Geophys. Res., 95, 10179-10192, https://doi.org/10.1029/JD095iD07p10179, 1990.

Roberts, J. M., Flocke, F., Chen, G., de Gouw, J., Holloway, J. S., Hübler, G., Neuman, J. A., Nicks, D. K., Nowak, J. B., Parrish, D. D., Ryerson, T. B., Sueper, D. T., Warneke, C., and Fehsenfeld, F. C.: Measurement of peroxycarboxylic nitric anhydrides (PANs) during the ITCT 2K2 aircraft intensive experiment, J. Geophys, Res.-Atmos., 109, D23S21, https://doi.org/10.1029/2004JD004960, 2004.

Roberts, J. M., Marchewka, M., Bertman, S. B., Sommariva, R., Warneke, C., de Gouw, J., Kuster, W., Goldan, P., Williams, E., Lerner, B. M., Murphy, P., and Fehsenfeld, F. C.: Measurements of PANs during the New England Air Quality Study 2002, J. Geophys. Res., 112, D20306, https://doi.org/10.1029/2007JD008667, 2007.

Rolph, G. D.: Real-time Environmental Applications and Display sYstem (READY) Website, NOAA Air Resources Laboratory, Silver Spring, MD, http://ready.arl.noaa.gov, 2012.

Saarikoski, S., Timonen, H., Saarnio, K., Aurela, M., Järvi, L., Keronen, P., Kerminen, V.-M., and Hillamo, R.: Sources of organic carbon in fine particulate matter in northern European urban air, Atmos. Chem. Phys., 8, 6281-6295, https://doi.org/10.5194/acp-8-6281-2008, 2008.

Schrimpf, W., Muller, K. P., Johnen, F. J., Lienaerts, K., and Rudolph, J.: An optimized method for airborne peroxyacetyl nitrate (PAN) measurements, J. Atmos. Chem., 22, 303-317, https://doi.org/10.1007/bf00696640, 1995.

Shang, X., Lee, M., Han, J., Kang, E., Gustafsson, Ö., and Chang, L.-S.: Identifiction and chemical characteristics of distinctive Chinese outflow plumes associated with enhanced submicron aerosols at the Gosan Climate Observatory, Aerosol Air Qual. Res., in review, 2017.

Staudt, A. C., Jacob, D. J., Ravetta, F., Logan, J. A., Bachiochi, D., Sandholm, S., Ridley, B., Singh, H. B., and Talbot, B.: Sources and chemistry of nitrogen oxides over the tropical Pacific, J. Geophys. Res., 108, 8239, https://doi.org/10.1029/2002JD002139, 2003.

Stjern, C. W., Samset, B. H., Myhre, G., Bian, H., Chin, M., Davila, Y., Dentener, F., Emmons, L., Flemming, J., Haslerud, A. S., Henze, D., Jonson, J. E., Kucsera, T., Lund, M. T., Schulz, M., Sudo, K., Takemura, T., and Tilmes, S.: Global and regional radiative forcing from $20 \%$ reductions in $\mathrm{BC}, \mathrm{OC}$ and $\mathrm{SO}_{4}-$ an HTAP2 multi-model study, Atmos. Chem. Phys., 16, 1357913599, https://doi.org/10.5194/acp-16-13579-2016, 2016.

Talukdar, R. K., Burkholder, J. B., Schmoltner, A. M., Roberts, J. M., Wilson, R. R., and Ravishankara, A. R.: Investigation of the loss processes for peroxyacetyl nitrate in the atmosphere: UV photolysis and reaction with $\mathrm{OH}, \mathrm{J}$. Geophys. Res., 100, 1416314173, https://doi.org/10.1029/95JD00545, 1995.

Tanimoto, H., Hirokawa, J., Kajii, Y., and Akimoto, H.: A new measurement technique of peroxyacetyl nitrate at parts per trillion by volume levels: Gas chromatography/negative ion chemical ionization mass spectrometry, J. Geophys. Res., 104, 21343-21354, https://doi.org/10.1029/1999JD900345, 1999.

Tanimoto, H., Furutani, H., Kato, S., Matsumoto, J., Makide, Y., and Akimoto, H.: Seasonal cycles of ozone and oxidized nitrogen species in northeast Asia, 1, Impact of regional climatology and photochemistry observed during RISOTTO 1999-2000, J. Geo- 
phys. Res., 107, 4747, https://doi.org/10.1029/2001JD001496, 2002.

Tanimoto, H., Matsumoto, K., and Uematsu, M.: Ozone-CO correlations in Siberian wildfire plumes observed at Rishiri Island, SOLA, 4, 65-68, https://doi.org/10.2151/sola.2008-017, 2008.

Tereszchuk, K. A., Moore, D. P., Harrison, J. J., Boone, C. D., Park, M., Remedios, J. J., Randel, W. J., and Bernath, P. F.: Observations of peroxyacetyl nitrate (PAN) in the upper troposphere by the Atmospheric Chemistry Experiment-Fourier Transform Spectrometer (ACE-FTS), Atmos. Chem. Phys., 13, 5601-5613, https://doi.org/10.5194/acp-13-5601-2013, 2013.

Tilmes, S., Lamarque, J.-F., Emmons, L. K., Kinnison, D. E., Ma, P.-L., Liu, X., Ghan, S., Bardeen, C., Arnold, S., Deeter, M., Vitt, F., Ryerson, T., Elkins, J. W., Moore, F., Spackman, J. R., and Val Martin, M.: Description and evaluation of tropospheric chemistry and aerosols in the Community Earth System Model (CESM1.2), Geosci. Model Dev., 8, 1395-1426, https://doi.org/10.5194/gmd8-1395-2015, 2015.

Wang, B., Shao, M., Roberts, J. M., Yang, G., Yang, F., $\mathrm{Hu}$, M., Zeng, L., Zhang, Y., and Zhang, J.: Groundbased on-line measurements of peroxyacetyl nitrate (PAN) and peroxypropionyl nitrate (PPN) in the Pearl River Delta, China, Int. J. Environ. Anal. Chem., 90, 548-559, https://doi.org/10.1080/03067310903194972, 2010.

Wang, Y., Zhang, Y., Hao, J., and Luo, M.: Seasonal and spatial variability of surface ozone over China: contributions from background and domestic pollution, Atmos. Chem. Phys., 11, 35113525, https://doi.org/10.5194/acp-11-3511-2011, 2011

Yang, F., He, K., Ye, B., Chen, X., Cha, L., Cadle, S. H., Chan, T., and Mulawa, P. A.: One-year record of organic and elemental carbon in fine particles in downtown Beijing and Shanghai, Atmos. Chem. Phys., 5, 1449-1457, https://doi.org/10.5194/acp5-1449-2005, 2005.

Zhang, H., Xu, X., Lin, W., and Wang, Y.: Wintertime peroxyacetyl nitrate (PAN) in the megacity Beijing: Role of photochemical and meteorological processes, J. Environ. Sci., 26, 83-96, https://doi.org/10.1016/S1001-0742(13)60384-8, 2014
Zhang, J. B., Xu, Z., Yang, G., and Wang, B.: Peroxyacetyl nitrate $(\mathrm{PAN})$ and peroxypropionyl nitrate $(\mathrm{PPN})$ in urban and suburban atmospheres of Beijing, China, Atmos. Chem. Phys. Discuss., 11, 8173-8206, https://doi.org/10.5194/acpd-11-81732011, 2011.

Zhang, J. M., Wang, T., Ding, A. J., Zhou, X. H., Xue, L. K., Poon, C. N., Wu, W. S., Gao, J., Zuo, H. C., Chen, J. M., Zhang, X. C., and Fan, S. J.: Continuous measurement of peroxyacetyl nitrate (PAN) in suburban and remote areas of western China, Atmos. Environ., 43, 228-237, https://doi.org/10.1016/j.atmosenv.2008.09.070, 2009.

Zhang, L., Jacob, D. J., Boersma, K. F., Jaffe, D. A., Olson, J. R., Bowman, K. W., Worden, J. R., Thompson, A. M., Avery, M. A., Cohen, R. C., Dibb, J. E., Flock, F. M., Fuelberg, H. E., Huey, L. G., McMillan, W. W., Singh, H. B., and Weinheimer, A. J.: Transpacific transport of ozone pollution and the effect of recent Asian emission increases on air quality in North America: an integrated analysis using satellite, aircraft, ozonesonde, and surface observations, Atmos. Chem. Phys., 8, 6117-6136, https://doi.org/10.5194/acp-8-6117-2008, 2008.

Zhao, B., Wang, S. X., Liu, H., Xu, J. Y., Fu, K., Klimont, Z., Hao, J. M., He, K. B., Cofala, J., and Amann, M.: NOx emissions in China: historical trends and future perspectives, Atmos. Chem. Phys., 13, 9869-9897, https://doi.org/10.5194/acp13-9869-2013, 2013.

Zhu, L., Fischer, E. V., Payne, V. H., Worden, J. R., and Jiang, Z.: TES observations of the interannual variability of PAN over Northern Eurasia and the relationship to springtime fires, Geophys. Res. Lett., 42, 7230-7237, dio:10.1002/2015GL065328, 2015.

Zhu, L., Payne, V. H., Walker, T. W., Worden, J. R., Jiang, Z., Kulawik, S. S., and Fischer, E. V.: PAN in the eastern Pacific free troposphere: A satellite view of the sources, seasonality, interannual variability, and timeline for trend detection, J. Geophys, Res.-Atmos., 122, 3614-3629, https://doi.org/10.1002/2016JD025868, 2017. 